Ethiopian Journal of Environmental Studies \& Management 8(Suppl. 2): 906 - 915, 2015.

ISSN:1998-0507

Submitted: May 19, 2015

doi: http://dx.doi.org/10.4314/ejesm.v8i2.5S

\title{
PHYTOTOXICITY EFFECT OF SPENT OIL ON Jatropha curcas SEEDLINGS USED IN SOIL PHYTOREMEDIATION
}

*IDOWU 0.D. ${ }^{1}$ AND FAYINMINNU 0.0. ${ }^{2}$

${ }^{1}$ Moist Forest Research Station, Forestry Research Institute of Nigeria, Benin City, Edo State ${ }^{2}$ Department of Crop Protection and Environmental Biology, University of Ibadan, Oyo State

\begin{abstract}
Soil contamination by Spent Lubricating Oil (SLO) is a growing concern in many African countries including Nigeria. Phytoremediation is an environmentally friendly and costeffective approach that is used in restoring such soils. This study employed Jatropha curcas seedlings in phytoremediating organically amended and unamended soil contaminated with 0,3 and $6 \%(w / w)$ SLO for 84 days. The possible effects of the polluted soil on the growing seedlings were investigated through a fortnight assessment of height growth, leaf production and stem diameter. The results showed significant differences $(P<0.05)$ in height, stem diameter and leaf production across the 0 (control), 3 and $6 \%$ levels of pollution on amended and unamended soil types investigated. The values recorded for growth parameters were dose dependent. At the end of twelve weeks, $0 \%$ pollution level recorded the highest mean height $(56.15 \mathrm{~cm})$, mean stem diameter $(7.42 \mathrm{~cm})$ and mean number of leaves (49.28). The mean height for $3 \%$ pollution level was $22.34 \mathrm{~cm}$ while mean diameter and mean leaf number were $3.86 \mathrm{~cm}$ and 10.23 respectively. Lowest values of mean height $(15.83 \mathrm{~cm})$, mean stem diameter $(2.81 \mathrm{~cm})$ and mean number of leaves (5.73) were obtained at $6 \%$ level of pollution. For amended soil, higher values of mean height $(43.04 \mathrm{~cm})$, mean stem diameter $(5.66 \mathrm{~cm})$ and mean number of leaves (34.96) were obtained as against mean values of $19.84 \mathrm{~cm}$, $3.74 \mathrm{~cm}$ and 8.54 of height, stem diameter and number of leaves for unamended soil. Although spent oil concentration had negative effect on the growth parameters investigated, it did not interfere with the phytoremediating process.
\end{abstract}

Key Words: $\quad$ Phytoremediation, Jatropha curcas, SLO, pollution

\section{Introduction}

The soil is an important component of the environment. It plays very significant roles as an abiotic component of the ecosystem by serving as the main medium of growth for plants and home to a large number of micro and macro organisms including bacteria, viruses, insects and worms (Adesodun and Nbagwu, 2008). The state of the soil is very important as it determines the quantity and quality of produce from it. According to Agamuthu et al. (2010) a fertile soil possessing all the essential nutrients for plant growth and with negligible contaminants will produce food materials with little or no detrimental effect on man and other animals. The global emphasis on soil health and sustainable food security is persuading soil scientists and toxicologists to consider rehabilitation of degraded lands especially

*Corresponding author: Idowu, O.D.

Email: dextop2011@gmail.com 
where oil contamination is involved (Nwoko, 2010).

Crude oil pollution is the most common form of oil based soil pollution. However, crude oil spills are often localized. In Nigeria, for example, most oil spill incidences occur in the Niger Delta area and directly affect the inhabitants of the communities involved. Another important oil-based soil pollutant is spent lubricant. The spent lubricant, otherwise called waste engine oil, spent engine oil or spent lubricating oil (SLO)) is usually obtained after servicing and subsequently draining lubricating oil from automobile and electric generator engines.

Pollution from SLO is an environmental problem which is more widespread than crude oil pollution (Odjegba and Sadiq, 2002).This is because SLO from automobiles, generators and other machines is indiscriminately dumped into the environment across the length and breadth of the country. Adegoroye (1997) reported that in Nigeria and some developing countries about 80 million litres of waste engine oil is generated annually from mechanic workshops and discharged indiscriminately into the environment. This renders the environment unsightly and constitutes a potential threat to humans, animals and vegetation (Adelowo et al., 2006).

Phytoremediation is an innovative technology that uses plants to remove environmental contaminants such as heavy metals and organic compounds (White et al., 2006; Jilani and Khan, 2006). It is a novel plant-based remediation technology applied to inorganic and organic contaminated soils, water and sediments all over the world which makes use of naturally occurring processes by which plants and their microbial rhizosphere fauna degrade and sequester organic and inorganic pollutants (Pradhan et al., 1998).
Jatropha curcas has been reported to be very useful in removing pollutants from the soil. For example, it is known to have been used on heavy metal polluted soils especially hexavalent chromium, in some countries of the world (Mangkoedihardjo et al., 2008). The increasing interest in Jatropha curcas for phytoremediation could be due to its high resistance and ability to thrive well in adverse conditions. It is also reported to be well adapted to acid and moisture demands and grow well on wasteland. This potential use of the species has made it imperative to carry out an investigation on its potential in the phytoremediation of spent oil polluted soil. (Agamuthu et al., 2010; Abioye et al., 2012; Chang et al., 2014).

\section{Methodology \\ Study Area}

The experiment was carried out at the Nursery Site of the Moist Forest Research Station $\left(6^{\circ} \quad 32^{\prime} \mathrm{N} \quad 5^{\circ} \quad 58^{\prime} \mathrm{E}\right)$, Forestry Research Institute of Nigeria (FRIN) Benin City, Edo State, Nigeria.

\section{Soil Sampling}

Top soil $(0-15 \mathrm{~cm})$ was collected from the Forest Floor of Acacia Plantation of the Research Station. The soil was thoroughly mixed and passed through a $2 \mathrm{~mm}$ sieve to remove the non-soil particulate. The chemical and physical properties of the soil including Heavy Metal Analysis were determined prior to introduction of the $J$. curcas. Contamination was done at 3 levels $(0 \%, 3 \%$ and $6 \% \mathrm{w} / \mathrm{w})$ of spent oil in $6 \mathrm{~kg}$ top soil and two classes of soil were used based on amendment with organic manure (amended and unamended soils). In both cases, the soil was thoroughly homogenized.

\section{Soil Preparation and Planting}

Six kilogramme $(6 \mathrm{~kg})$ polythene pots were utilized for the experiment. Experimental Design was $2 \times 3$ Factorial in 
a Completely Randomized Design and replicated 3 times. The first factor was soil amendment (amended and unamended soil) and the second factor was three levels of spent oil pollution $(0 \%, 3 \%$ and $6 \%$ weight by weight $(\mathrm{w} / \mathrm{w}))$. Ten seedlings were used for each level of pollution, translating to 30 seedlings per replicate and a total of 180 seedlings (90 seedlings for amended soil and 90 seedlings for unamended soil) for the experimental setup.

The pots were filled with topsoil, thoroughly mixed for even distribution of introduced organic manure $(10 \% \mathrm{w} / \mathrm{w})$ and spent oil contaminants and watered to field capacity. Earlier raised seedlings of $J$. curcas were transplanted to the polluted soils at 3 weeks after planting.

Based on the setup, the treatment combinations used in this study were:

Unamended (w/w)

$0 \%$ level of contamination

$6 \mathrm{~kg}$ topsoil+0 $\mathrm{kg}$ spent lubricating oil $\left(\mathrm{NP}_{0}\right)$

$3 \%$ level of contamination
$6 \mathrm{~kg}$ topsoil $+0.18 \mathrm{~kg}$ of spent lubricating oil $\left(\mathrm{NP}_{3}\right)$

$6 \%$ level of contamination

$6 \mathrm{~kg}$ topsoil $+0.36 \mathrm{~kg}$ of spent lubricating oil $\left(\mathrm{NP}_{6}\right)$

Amended (w/w)

$0 \%$ level of contamination

$6 \mathrm{~kg}$ topsoil $+0 \mathrm{~kg}$ spent lubricating oil +0.6 $\mathrm{kg}$ Organic Manure $\left(\mathrm{AP}_{0}\right)$

$3 \%$ level of contamination

$6 \mathrm{~kg}$ topsoil $+0.18 \mathrm{~kg}$ of spent lubricating oil $+0.6 \mathrm{~kg}$ Organic Manure $\left(\mathrm{AP}_{3}\right)$

$6 \%$ level of contamination

$6 \mathrm{~kg}$ topsoil $+0.36 \mathrm{~kg}$ of spent lubricating oil $+0.6 \mathrm{~kg}$ Organic Manure $\left(\mathrm{AP}_{6}\right)$

\section{Data Collection}

Growth parameters such as plant height, number of leaves and stem diameter were measured using metre rule, visual count and venier calliper respectively starting from four weeks after planting (WAP) at two weeks interval for twelve weeks. This was done on five randomly selected seedlings from each treatment class (level of pollution).

\section{Results}

Table 1: Physicochemical Properties of Soil and Organic Manure used for Phytoremediation

\begin{tabular}{lll}
\hline PARAMETERS $(\%)$ & ORGANIC MANURE & $\mathrm{NP}_{0}$ \\
\hline Organic Carbon & 36.38 & 0.93 \\
Sand & 6.26 & 91.84 \\
Silt & 0.00 & 4.67 \\
Clay & 0.00 & 3.49 \\
$\mathrm{pH}$ & 5.78 & 6.85 \\
Nitrogen $(\mathrm{N})$ & 2.13 & 0.12 \\
Calcium $(\mathrm{Ca})$ & 1.18 & 0.008 \\
Magnesium $(\mathrm{Mg})$ & 0.67 & 0.003 \\
Potassium $(\mathrm{K})$ & 1.03 & 0.011 \\
Sodium $(\mathrm{Na})$ & 0.49 & 0.006 \\
\hline
\end{tabular}

$\mathrm{N}$ - Unamended Soil

$\mathrm{P}_{0 .}$ 0\% Pollution Level 
Table 2: Effects of Pollution Levels and Soil Amendment on Mean Heights of J. curcas Seedlings used in Phytoremediation

\begin{tabular}{lllllll}
\hline \multirow{2}{*}{ Treatments } & \multicolumn{5}{c}{ Height $(\mathrm{cm})$} \\
\cline { 2 - 7 } & 2 WAT & 4 WAT & 6 WAT & 8 WAT & $10 \mathrm{WAT}$ & $12 \mathrm{WAT}$ \\
\hline Soil Amendment & & & & & & \\
AS & $14.54 \mathrm{a}$ & $17.55 \mathrm{a}$ & $22.18 \mathrm{a}$ & $30.24 \mathrm{a}$ & $37.35 \mathrm{a}$ & $43.04 \mathrm{a}$ \\
NAS & $11.98 \mathrm{~b}$ & $13.03 \mathrm{~b}$ & $13.97 \mathrm{~b}$ & $15.96 \mathrm{~b}$ & $17.80 \mathrm{~b}$ & $19.84 \mathrm{~b}$ \\
SE \pm & 0.21 & 0.41 & 0.45 & 0.70 & 0.78 & 1.31 \\
Pollution Levels & & & & & & \\
0 & $15.36 \mathrm{a}$ & $19.26 \mathrm{a}$ & $26.01 \mathrm{a}$ & $36.27 \mathrm{a}$ & $46.45 \mathrm{a}$ & $56.15 \mathrm{a}$ \\
3 & $12.53 \mathrm{~b}$ & $13.54 \mathrm{~b}$ & $14.59 \mathrm{~b}$ & $18.85 \mathrm{~b}$ & $21.07 \mathrm{~b}$ & $22.34 \mathrm{~b}$ \\
6 & $11.90 \mathrm{~b}$ & $13.11 \mathrm{~b}$ & $13.63 \mathrm{~b}$ & $14.19 \mathrm{c}$ & $15.20 \mathrm{c}$ & $15.83 \mathrm{c}$ \\
SE \pm & 0.26 & 0.51 & 0.55 & 0.86 & 0.96 & 1.60 \\
\hline
\end{tabular}

Values are means \pm S.E

Means with the same alphabets are not significantly different at 5\% level of significance using DMRT WAT - Weeks after Transplanting

AS - Amended Soil

NAS - Unamended Soil

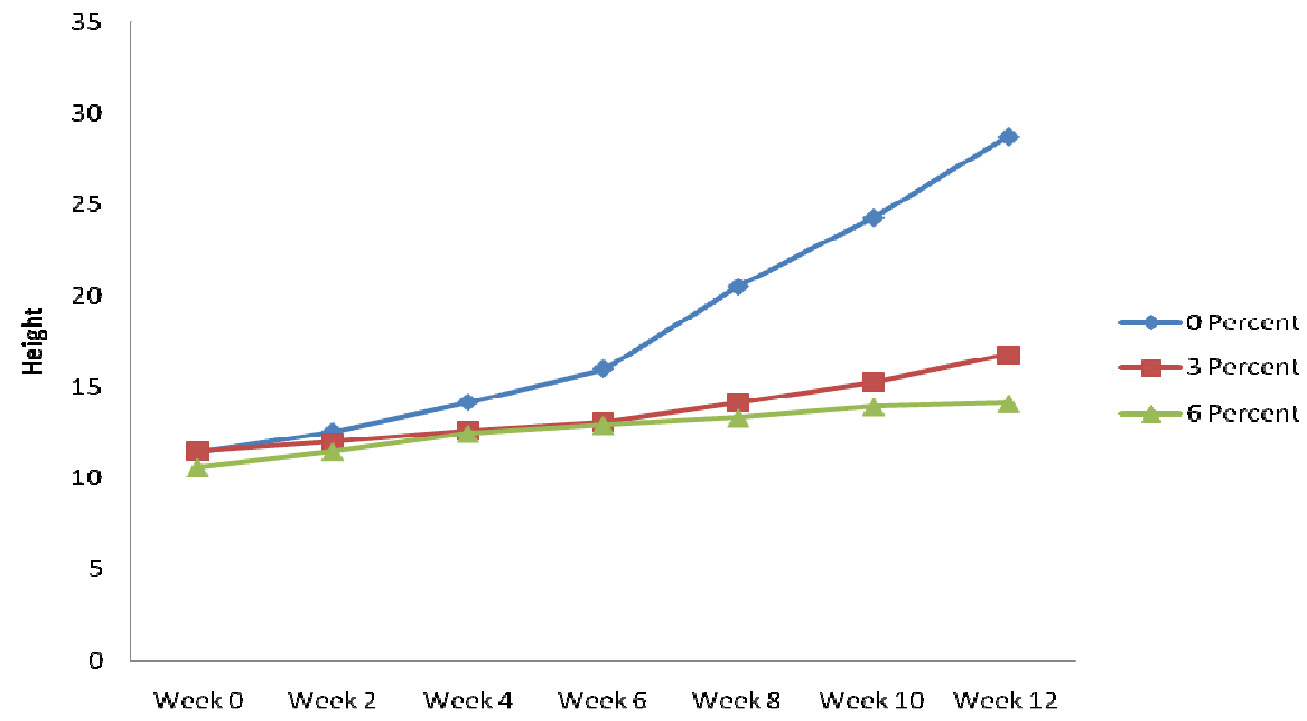

Figure 1: Plant height of Jatropha curcas as affected by Spent Lubricating Oil (SLO) concentration in amended FRIN Soil 


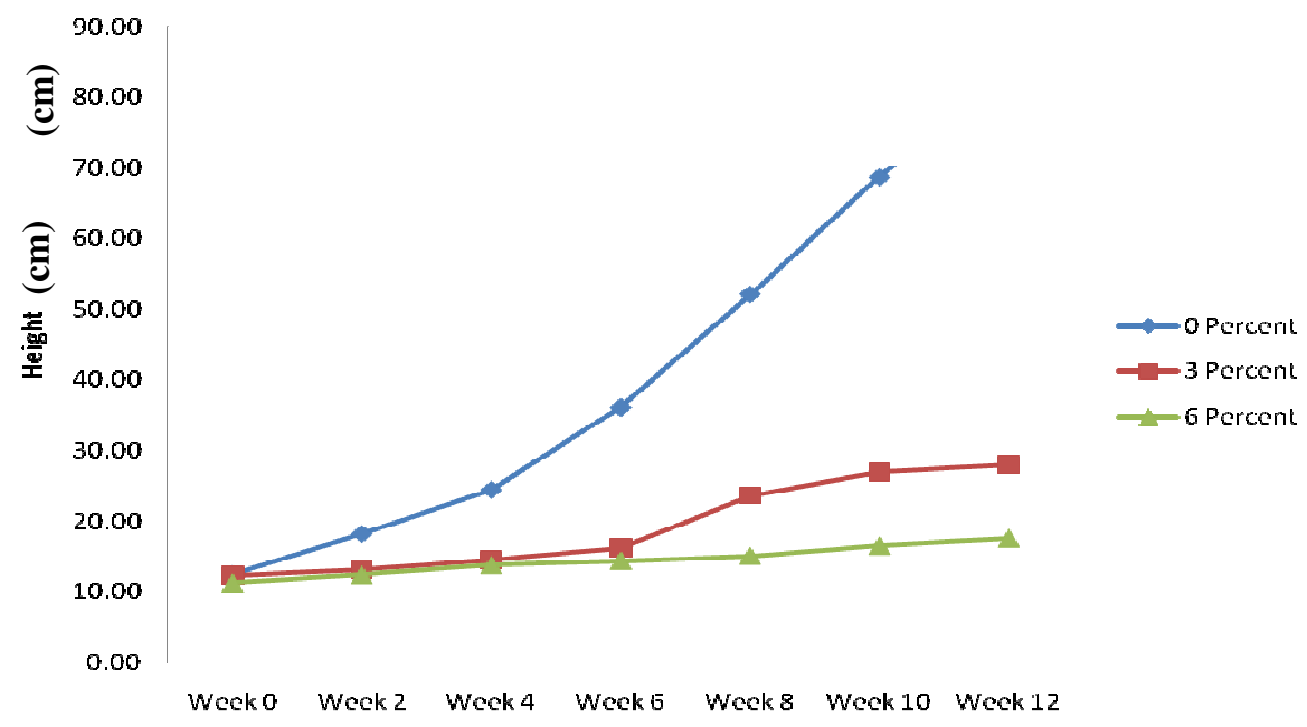

Figure 2: Plant height of Jatropha curcas as affected by Spent Lubricating Oil (SLO) concentration in unamended FRIN Soil

TABLE 3: Effects of Pollution Levels and Soil Amendment on Stem Diameter of J. curcas Seedlings

\begin{tabular}{lllllll}
\hline \multirow{2}{*}{ Treatments } & \multicolumn{5}{c}{ Stem Diameter $(\mathrm{cm})$} \\
\cline { 2 - 7 } & 2 WAT & 4 WAT & 6 WAT & 8WAT & 10WAT & 12 WAT \\
\hline Soil Types & & & & & & \\
AS & $2.27 \mathrm{a}$ & $2.63 \mathrm{a}$ & $3.68 \mathrm{a}$ & 4.31 & $4.85 \mathrm{a}$ & $5.66 \mathrm{a}$ \\
NAS & $2.10 \mathrm{~b}$ & $2.33 \mathrm{~b}$ & $2.86 \mathrm{~b}$ & 3.09 & $3.25 \mathrm{~b}$ & $3.74 \mathrm{~b}$ \\
SE \pm & 0.21 & 0.048 & 0.05 & 0.07 & 0.11 & 0.11 \\
Pollution Levels & & & & & & \\
0 & $2.65 \mathrm{a}$ & $3.14 \mathrm{a}$ & $4.60 \mathrm{a}$ & $5.43 \mathrm{a}$ & $6.05 \mathrm{a}$ & $7.42 \mathrm{a}$ \\
3 & $1.96 \mathrm{~b}$ & $2.19 \mathrm{~b}$ & $2.74 \mathrm{~b}$ & $3.13 \mathrm{~b}$ & $3.47 \mathrm{~b}$ & $3.86 \mathrm{~b}$ \\
6 & $1.95 \mathrm{~b}$ & $2.11 \mathrm{~b}$ & $2.46 \mathrm{c}$ & $2.54 \mathrm{c}$ & $2.62 \mathrm{c}$ & $2.81 \mathrm{c}$ \\
SE \pm & 0.03 & 0.58 & 0.06 & 0.08 & 0.14 & 0.13 \\
\hline
\end{tabular}

Values are means \pm S.E

Means with the same alphabets are not significantly different at $5 \%$ level of significance using DMRT WAT - Weeks after Transplanting

AS - Amended Soil

NAS - Unamended Soil 


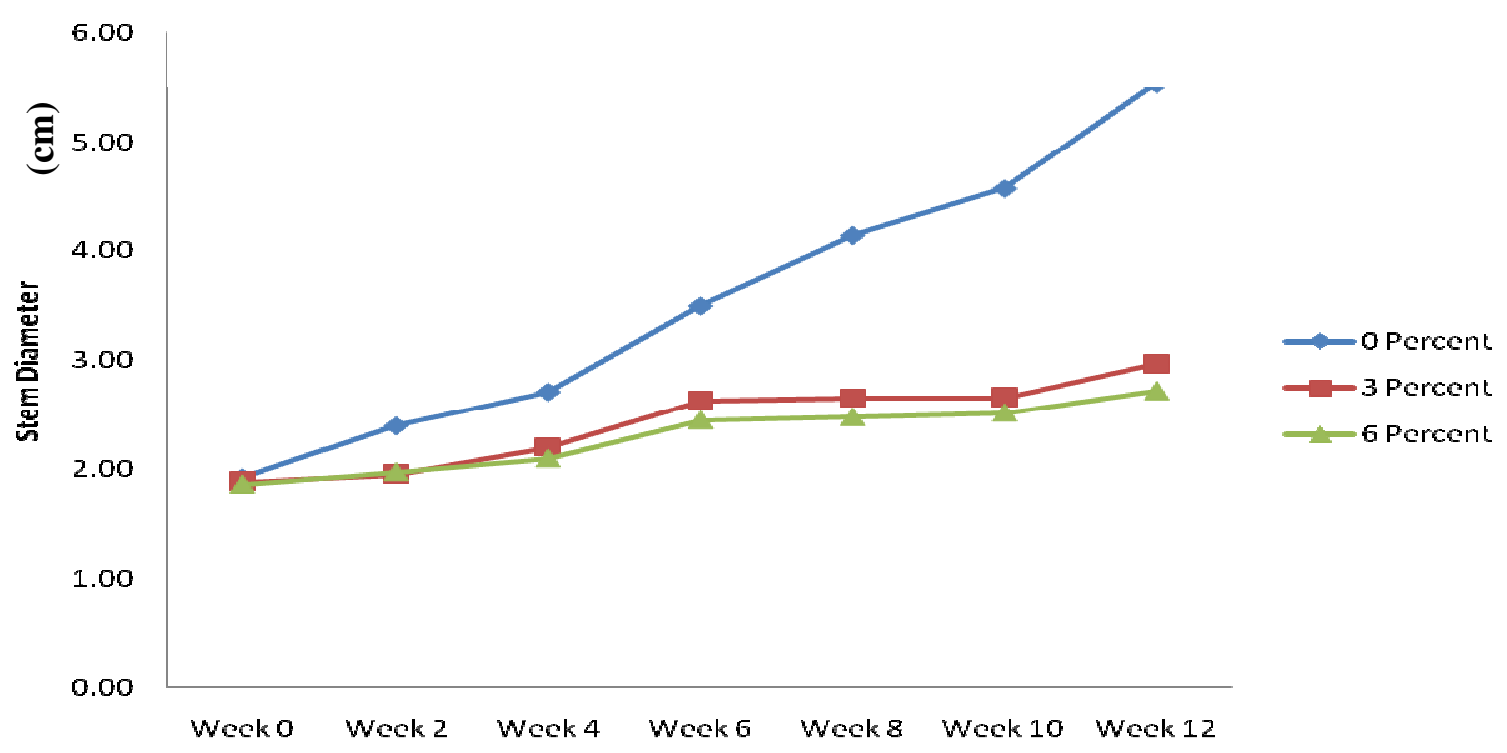

Figure 3: Stem Diameter of Jatropha curcas as affected by Spent Lubricating Oil (SLO) concentration in unamended FRIN Soil

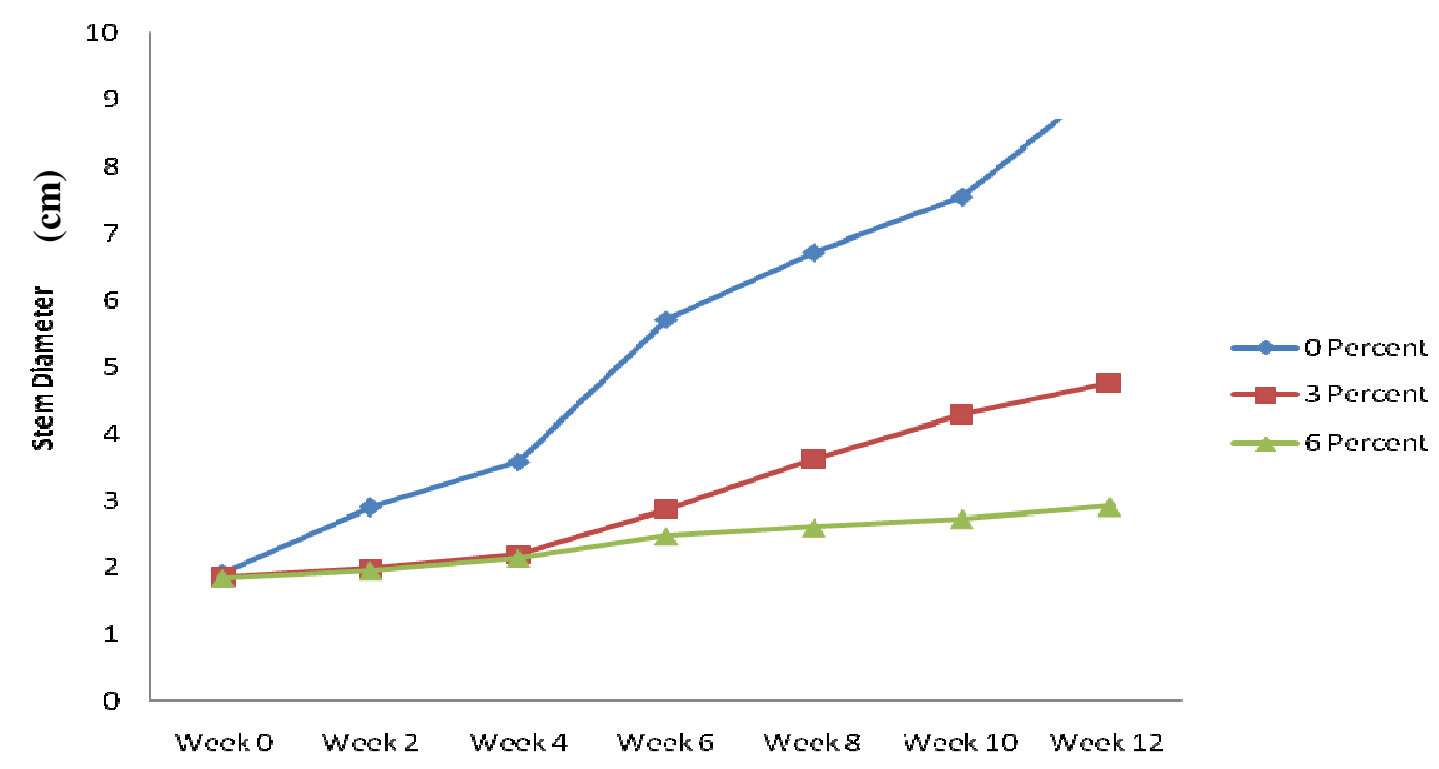

Figure 4: Stem diameter of Jatropha curcas as affected by Spent Lubricating Oil (SLO) concentration in amended FRIN Soil 
Table 4: Effects of Pollution Levels and Soil Amendment on Mean Number of Leaves of $J$. curcas Seedlings

\begin{tabular}{lllllll}
\hline \multirow{2}{*}{ Treatments } & \multicolumn{5}{c}{ Number of Leaves } \\
\cline { 2 - 7 } & 2 WAT & 4 WAT & 6 WAT & 8 WAT & $10 \mathrm{WAT}$ & $12 \mathrm{WAT}$ \\
\hline Soil Amendment & & & & & & \\
AS & $5.40 \mathrm{a}$ & $8.80 \mathrm{a}$ & $19.09 \mathrm{a}$ & $28.03 \mathrm{a}$ & $30.12 \mathrm{a}$ & $34.96 \mathrm{a}$ \\
NAS & $4.90 \mathrm{~b}$ & $5.29 \mathrm{~b}$ & $6.22 \mathrm{~b}$ & $6.68 \mathrm{~b}$ & $7.69 \mathrm{~b}$ & $8.54 \mathrm{~b}$ \\
SE \pm & 0.15 & 0.43 & 0.52 & 3.87 & 0.99 & 0.45 \\
Pollution Levels & & & & & & \\
0 & $7.83 \mathrm{a}$ & $11.87 \mathrm{a}$ & $26.93 \mathrm{a}$ & $31.67 \mathrm{a}$ & $41.97 \mathrm{a}$ & $49.28 \mathrm{a}$ \\
3 & $4.00 \mathrm{~b}$ & $4.87 \mathrm{~b}$ & $6.17 \mathrm{~b}$ & $15.55 \mathrm{~b}$ & $9.67 \mathrm{~b}$ & $10.23 \mathrm{~b}$ \\
6 & $3.63 \mathrm{~b}$ & $4.40 \mathrm{~b}$ & $4.87 \mathrm{c}$ & $4.85 \mathrm{c}$ & $5.08 \mathrm{c}$ & $5.73 \mathrm{c}$ \\
SE \pm & 0.19 & 0.53 & 0.63 & 4.74 & 1.21 & 5.73 \\
\hline Valles are & & & & & &
\end{tabular}

Values are means \pm S.E

Means with the same alphabets are not significantly different at 5\% level of significance using DMRT WAT - Weeks after Transplanting

AS - Amended Soil

NAS - Unamended Soil

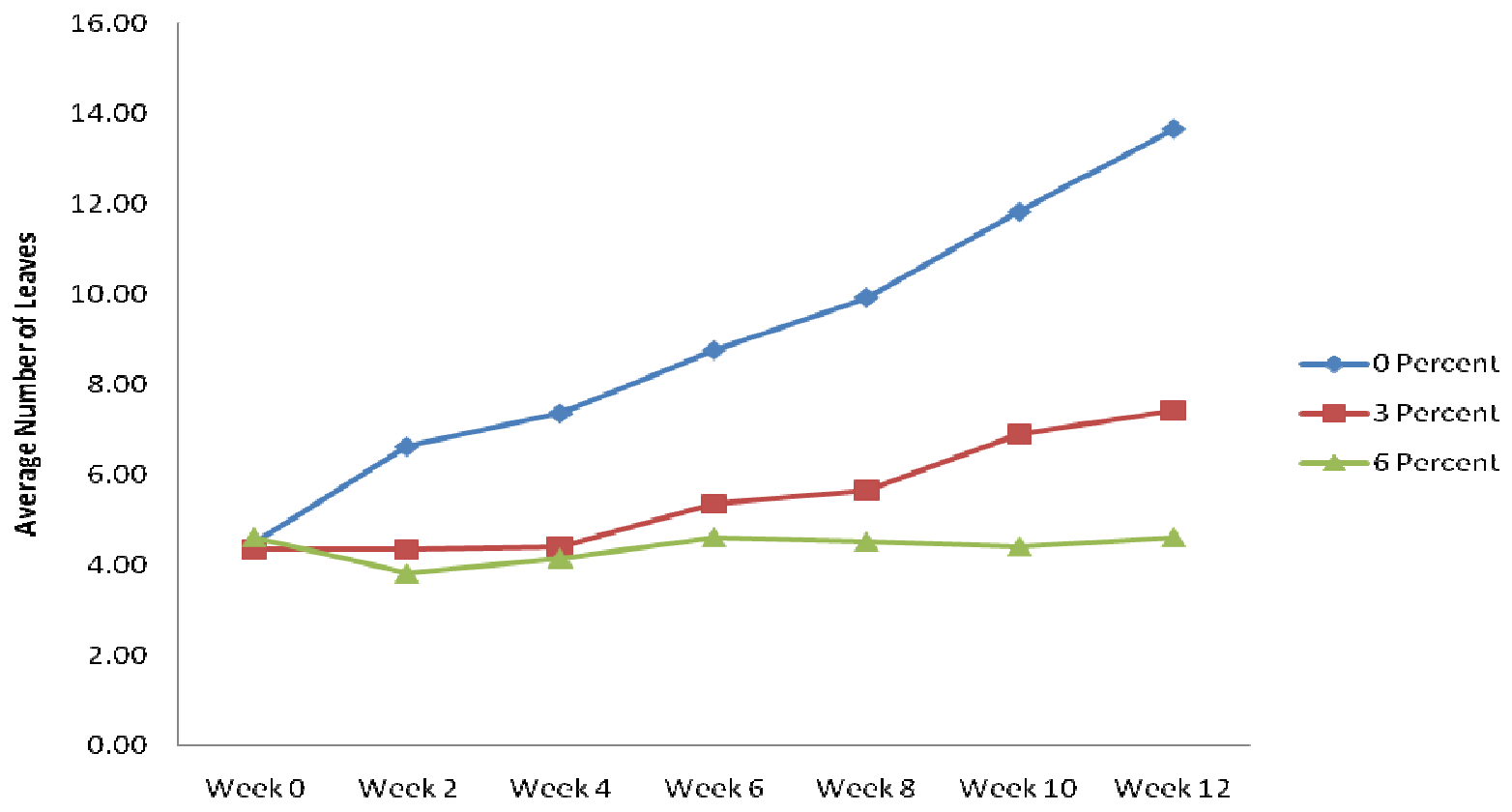

Figure 5: Number of Leaves of Jatropha curcas as affected by Spent Lubricating Oil (SLO) concentration in unamended FRIN Soil 


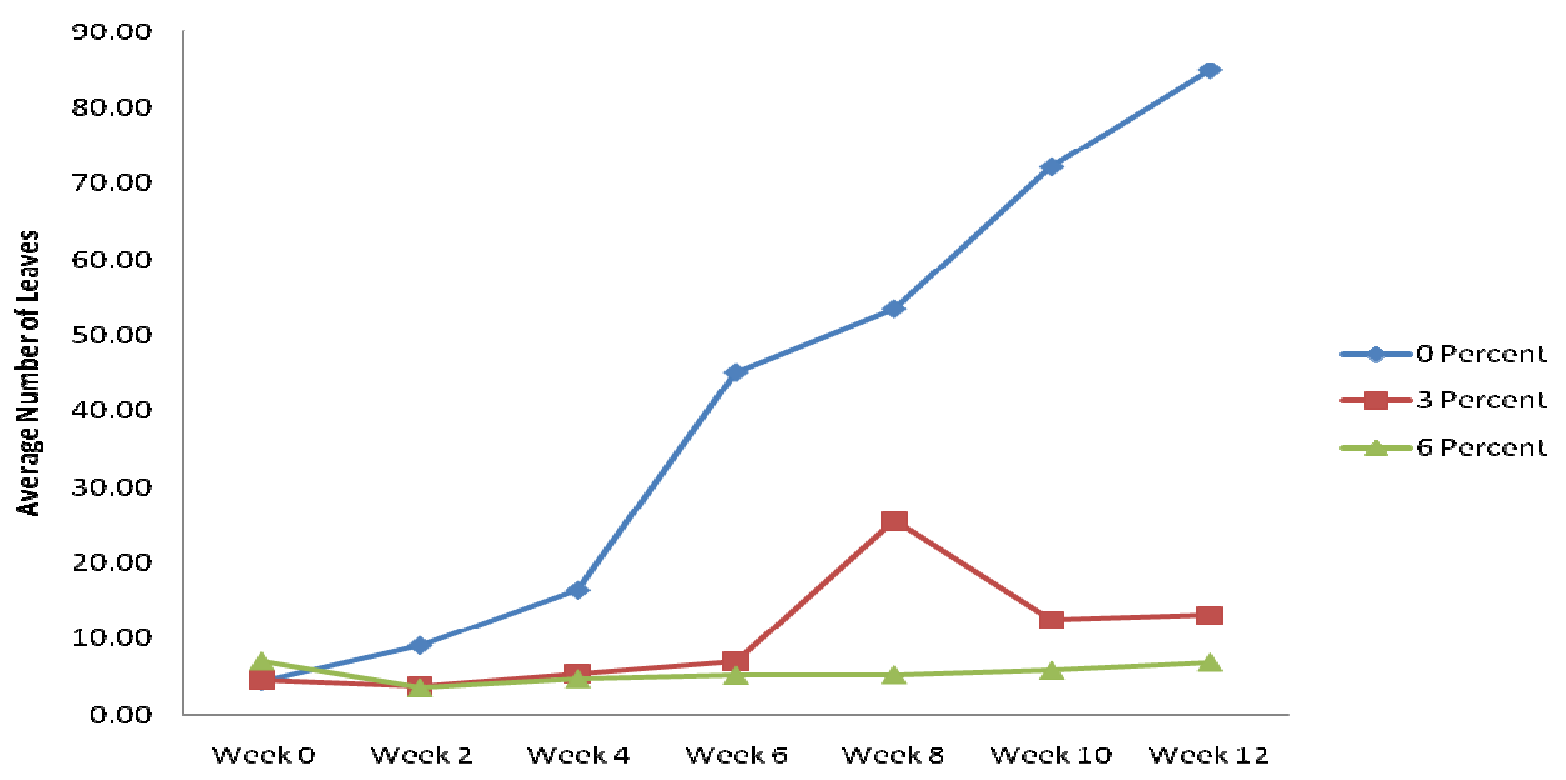

Figure 6: Number of Leaves of Jatropha curcas as affected by Spent Lubricating Oil (SLO) concentration in amended FRIN Soil

The tables and figures above summarize the observable growth variations during the experiment. At the end of twelve weeks, $0 \%$ pollution level recorded the highest mean height $(56.15 \mathrm{~cm})$, mean stem diameter $(7.42 \mathrm{~cm})$ and mean number of leaves (49.28). The mean height for $3 \%$ pollution level was $22.34 \mathrm{~cm}$ while mean diameter and mean leaf number were $3.86 \mathrm{~cm}$ and 10.23 respectively. Lowest values of mean height $(15.83 \mathrm{~cm})$, mean stem diameter $(2.81 \mathrm{~cm})$ and mean number of leaves (5.73) were obtained at $6 \%$ level of pollution. For amended soil, higher values of mean height $(43.04 \mathrm{~cm})$, mean stem diameter $(5.66 \mathrm{~cm})$ and mean number of leaves (34.96) were obtained as against mean values of $19.84 \mathrm{~cm}, 3.74 \mathrm{~cm}$ and 8.54 of height, stem diameter and number of leaves for unamended soil.

The results showed significant differences $(\mathrm{P}<0.05)$ in height, stem diameter and leaf production across the 0 (control), 3 and $6 \%$ levels of pollution on amended and unamended soil types investigated (Tables 2, 3 and 4 respectively).

\section{Discussion and Conclusion}

A summary of the observations on growth parameters shows that soil amendment resulted in better performance in terms of mean height, mean stem diameter and mean number of leaves. On the other hand, increased contamination of soil with SLO (3 and 6\% levels of contamination) had observable adverse effects on the growth parameters. This observation is in conformity with Odjegba and Sadiq (2002) who examined effects of spent engine oil on the growth of Amaranthus hybridus and reported that the mean height of the control was significantly greater than those of plants grown on soil treated with $1-5 \%$ spent engine oil. This was corroborated by Vwioko and Fashemi (2005) who investigated growth response of five different plant species in soil supplemented with spent lubricating oil at $1-6 \% \mathrm{w} / \mathrm{w}$ 
strengths and concluded that the growth parameters demonstrated an overall dose dependent response. Sharifi et al., (2007) also alluded to the fact that spent oil has detrimental effects on germination rate and above ground height of plants. They stated that the various responses of plant species to spent oil contaminant appear to be dose dependent.

The reduction in plant growth parameters may be due to the effects of aliphatic, aromatic and phenolic compounds that reduce respiration, transpiration and photosynthesis as well as systemic toxic effect of translocation of long chain alkanes to stems (Trap et al., 2005). Molina-Barahona et al., (2005) inferred that it could also be due to the impermeability effect of the fuel, the immobilization of nutrients mainly nitrogen and by inhibitory effects of some of the polycyclic aromatic hydrocarbon components. Various studies have shown that the dynamics of solubilization and ionic exchange in soils have been negatively affected under the influence of Spent Lubricating Oil (Odjegba and Sadiq, 2002).

In conclusion, this study has been able to show that;

- J. curcas seedlings can survive on SLO contaminated soil of 0,3 and $6 \%$ contamination levels as a phytoremediator.

- Negative effect of SLO on growth parameters such as height, stem diameter and number of leaves is dose dependent. The dose dependent effect on growth parameters did not interfere with the phytoremediating function of the species at the level of pollution investigated.

\section{References}

Abioye, O.P., Agamathu, P. and Abdul Aziz, A.R. (2012). Biodegradation of used motor oil using organic waste amendment. Biotechnology Research International, Article ID 587041, 8 pages

http://dx.doi.org/10.1155/2012/587041

Adegoroye, G. (1997). Environmental Considerations property design, urban development and renewal. In O. Akinjide (Ed.), Dimensions of environmental problems in Nigeria (pp 12 -25), Washinton, Friedrich Ebert Foundation.

Adelowo, O.O., Alagbe, S.O. and Ayandele, A.A. (2006). Timedependent stability of used engine oil degradation by cultures of Pseudomonas fragi and Achromobacter aerogens. African Journal of Biotechnology, 5(24): $2476-2479$.

Adesodun, J.K. and Nbagwu J.S.C. (2008). Biodegradation of waste lubricating petroleum oil in a tropical alfisol as mediated by animal droppings. Bioresource technology 99, 5659 5665.

Agamuthu, P., Abioye, O.P. and Azeez, A.A. (2010). Phytoremediation of soil contaminated with used lubricating oil with Jatropha curcas. Journal of Hazardous Materials, 179: (1-3): 891 - 894.

Chang, F.C., Ko, C.H., Tsai, M.J., Wang, Y.N. and Chung, C.Y. (2014). Phytoremediation of heavy metal contaminated woil by Jatropha curcas. Journal of Ecotoxicology, 23(10): 1969-1978.

Jilani, S. and Khan, M.A., (2006). Biodegradation of Cypermethrin by Pseudomonas in a batch activated sludge process. Int. J.Environ. Sci. Tech., 3(4): 371-380.

Mangkoedihardjo, S., Ratnawati R. and Alfianti, N. (2008). Phytoremediation of Hexavalent Chromium Polluted 
Soil Using Pterocarpus indicus and Jatropha curcas L. World Applied Sciences Journal, 4(3): 338-342.

Molina-Barahona, L., Vega-Loyo, L., Guerrero, M., Ramirez, S., Romero, I., Vega-Jarquin, C. and Albores, A. (2005). Ecotoxicological Evaluation of Diesel-Contaminated Soil Before and After a Bioremediation Process. www.interscience.wiley.com pp.100109.

Nwoko, C.O. (2010). Trends in phytoremediation of toxic elemental and organic pollutants. African Journal of Biotechnology, 9(37): 6010-6016.

Odjegba, V. and Sadiq, A.O. (2002). Effects of spent engine oil on the growth parameters, chlorophyll and protein levels of Amaranthus hybridus L. The Environmentalist, 22: 23-28.
Pradhan, S.P., Conrad, J.R., Paterek, J.R. and Srivastava, V.J. (1998). Potential of phytoremediation for treatment PAHs in soil at MGP sites. J. Soil Contamination. 7: 467-480.

Sharifi, M. Sadeghi, Y. and Akbarpour, M. (2007). Germination and growth of six plant species on contaminated soil with spent oil. Int. J. Environ. Sci. Tech., 4(4): 463-470.

Vwioko, D.E. and Fashemi, D.S. (2005). Growth Response of Ricinus communis L (Castor Oil) in Spent Lubricating Oil Polluted soil. J. Appl. Sci. Environ. Manage., 9(2): 73-79.

White, P.M., Wolf, D.C., Thoma, G.J. and Reynolds, C.M. (2006). Phytoremediation of alkylated polycyclic aromatic hydrocarbons in a crude oil contaminated soil. Water, Air, Soil Pollut., 169: 207-220. 